\title{
DEFINING SECOND-TIER AUDIT FIRMS IN SERBIA: IN SEARCH OF THE SMALL FOUR
}

\author{
Nemanja Stanišić*, Vule Mizdraković, Tijana Radojević, Nenad Stanić \\ Singidunum University, 32 Danijelova St., Belgrade, Serbia
}

\begin{abstract}
:
In this paper, we aim to define the so-called "second tier" audit firms in the Republic of Serbia. In order to accomplish that, we have analyzed 10,555 financial statements of legal entities operating on the territory of the Republic of Serbia for the period 2010-2012. The "Big 4" audit firms have audited 1,101 of the aforementioned financial statements, whereas the rest of the statements have been audited by the remaining 38 audit firms. For the purpose of training a decision tree classification algorithm, a number of calculated financial indicators of audited entities and corresponding audit opinions issued by the "Big 4" firms have been treated as independent and dependent variables, respectively. The resulting set of rules was then applied to the rest of the sample. Based on the observed level of compliance with the "Big 4" criteria (which stands for high quality audit), we have subsequently suggested the "Small 4 " audit firms in Serbia. Moreover, the results show that the "Big 4" firms and the other audit firms assign different importance to independent variables. The paper also discusses possible reasons for that and offers recommendations for future research.
\end{abstract}

\section{Key words:}

decision trees,

financial statements, audit opinion.

\section{INTRODUCTION}

The recent financial crises have resulted in the bankruptcy of numerous entities and financial institutions globally. However, their financial statements should have shown some indices of higher financial risk prior to their default. For this reason, the public gaze is once again turned to auditors and audit firms. All major stakeholders are aware of the auditor's role in disclosing whether the entity would carry on with its business or not. Empirical evidence from prior studies also shows that only about half of the public companies in the United States that subsequently entered into bankruptcy received a GCO (going-concern opinion) on the last set of financial statements filed prior to bankruptcy (Geiger et al., 2014). Much higher expectations have been laid upon the Big 4, since it is presumed that those auditors provide opinions of a higher quality due to their size and supposedly superior auditing methodologies (DeAngelo, 1981). Compared to other audit firms, they should make fewer Type I and Type II errors. The first type refers to issuance of modified opinion to healthy clients, while the second one refers to issuance of unmodified opinion to clients that have material misstatements in their financial reports or noteworthy going-concern issues. Both types are undesirable with respect to auditor's reputation. Type I errors might lead to auditorswitching and loss of potential revenue, followed by extra costs for acquiring new clients. On the other hand, in cases of issuance of unmodified opinion to the client that went bankrupt, an auditor may face lawsuit costs.

Second-tier audit firms in the United States gained their strength predominantly in the post SOX (Sarbanes-Oxley Act of 2002) era. The SOX has had two effects on the audit service market: firstly, it increased the demand for high-quality auditing, especially from 
publicly traded companies (SEC clients); and secondly, it temporarily eclipsed the Big 4's reputation for competence. During the period 2003-2005, second-tier auditors observed a 23\% (166) increase in SEC clients, whereas the Big 4 faced a decrease of $9 \%$ (652) over the same period (Dey \& Robin, 2011). The recent financial crisis has provided audit clients with the long awaited excuse to switch from the Big 4 to second or third-tier firms (Hogan \& Martin, 2009).

Throughout the world, members of the Big 4 (formerly the Big 8 and the Big 6 ) are considered to be top-level audit firms, and their reputation in the Republic of Serbia does not differ in this respect. Unlike the Big 4, which is comprised of large and reputable international firms, second-tier auditors usually have a more national or local reach. For that reason, they can (and should be) be defined independently for each country according to the available evidence on the quality level of their audit services. To the best of our knowledge, a clear definition of second-tier audit firms in Serbia has not yet been delivered.

Therefore, the principal goal of this paper - and hence its key potential contribution - is to identify second-tier audit firms in Serbia. We aim to accomplish that by examining the levels of accordance (discordance) in audit opinions issued by different groups of audit firms in the sample (by the members of the Big 4 and by the other 38 audit firms that actively operate in Serbia). Additionally, the methodology and results presented in this paper may serve as a reference for future research with the aim to define the second- tier audit firms in other countries. The structure of the paper is as follows. In the next section, we discuss the theoretical background of this study. This is followed by a description of the research method and calculations. Upon presenting the research results, the paper concludes with a short discussion and provides recommendations for future research.

\section{THEORETICAL APPROACH}

There are numerous definitions of audit quality in the literature. For instance, DeAngelo (1981) defines it as "the joint probability that auditors will detect and report a breach in their client's accounting system". Dopuch and Simunic (1982) define it as a possibility that audited financial statements are more likely to be free from intentional misrepresentation (DeAngelo, 1981; DeFond, 1992). Based on the definitions provided, a conclusion can be drawn that audit quality is a characteristic that refers to the ability of audit procedures to decrease the agency conflict between the owners of an entity and its management. The aforementioned authors argue that auditors typically specialize in providing auditing services of a certain level of quality to retain their clients and establish distinguishing reputation. Therefore, they will most likely refuse an engagement that demands different levels of audit quality, since such arrangements would be cost-ineffective. However, it should not be disregarded that there are different performance dimensions of audit firms (Causse \& Vu, 2012). Still, based on the previous statements, it can be supposed that an auditor's size can serve as an appropriate proxy for the level of quality of its services.

The authors of related research on audit quality (Geiger \& Rama, 2006) concluded that both Type I and Type II error rates are significantly lower for the Big 4 firms compared to the non-Big 4 firms. They did not find significant differences between second and third-tier audit firms with respect to either type of reporting error (Geiger \& Rama, 2006). Therefore, a higher quality of services provided by first-tier auditors should justify their premium fees. According to Dey and Robin (2011), the Big 4 provide audit services to more than $80 \%$ of SEC-listed firms and capture more than $90 \%$ of total audit fees paid by these firms. In addition, the Big 4 members account for upwards of $60 \%$ of audit revenues in the Republic of Serbia (Jakšić et al., 2012). Research conducted in the United Kingdom by Campa (2013) supports the claim that audit fee premiums are only charged by the Big 4 firms. However, the same author did not find a significant association between audit quality and type of auditor.

Besides its main purpose, external auditing ought to be able to inhibit the earnings management practice. Statistically, the estimated effects of earnings management (i.e. discretionary earnings) are frequently used as a proxy for audit quality, and consequently for defining second-tier firms. However, we have not pursued this approach herein because of the specifics of the local economy. More precisely, even though the authors such as Becker et al. (1998) and Palmrose (1988) have proven to be right in the presumption of an auditor's ability to prevent earnings management practice in developed countries such as the United States, the same does not hold for developing countries such as Turkey and Greece (Tsipouridou \& Spathis, 2012; Yaşar, 2013). Therefore, we believe that in this particular case, it is more appropriate to rely on the aforementioned assumption of the "size/international reputation effect" on audit quality. 
In order to accomplish the previously defined research goal, we have collected 11,096 financial statements issued by legal entities headquartered in Serbia, specifically those that have a legal obligation to arrange an external audit of their annual financial statements (i.e. all medium-sized and large entities, in terms of the local rules on size classification, as well as public companies). The financial reports of the sample entities have been collected from the official online data service maintained by the relevant national agency. After that, we have calculated a number of widely used financial indicators, which are presented in Table 1. The auditors are advised to do the same when considering a going concern issue.

\begin{tabular}{|c|}
\hline Financial indicator \\
\hline Total revenues \\
\hline Debt-to-total assets ratio \\
\hline Interest-bearing debt-to-total assets ratio \\
\hline Net margin \\
\hline Operating margin \\
\hline Return on equity \\
\hline Return on assets \\
\hline Current ratio \\
\hline Quick ratio \\
\hline Cash ratio \\
\hline Interest coverage ratio \\
\hline Days sales outstanding \\
\hline Days payable outstanding \\
\hline Inventory conversion period \\
\hline Cash conversion period \\
\hline Asset-turnover ratio \\
\hline Fixed assets-to-total assets ratio \\
\hline Foreign ownership \\
\hline Average monthly salary \\
\hline Z' score for private firms implied default probability \\
\hline Market share \\
\hline
\end{tabular}

Table 1. List of financial indicators used in the research

Most of the listed financial indicators are self-explanatory. Nevertheless, it should be pointed out that Altman's Z-score is a product of discriminant analysis rather than of logistic regression. Consequently, the probabilities of bankruptcy calculated by the transformation function are actually quasi-probabilities that are not exactly equivalent to those obtained in logistic regression procedures. The values obtained in such way are surely directionally correct, and predominantly magnitudinaly correct.

Authors in the field of audit quality research, such as Geiger and Rama (2006), typically collect data on a group of business entities and split them into two groups based on whether or not they have ceased operations during the observation period. Subsequently, they examine if audit opinions from previous reporting periods have stressed going concern issues for those that have ceased operations. However, using the aforementioned methodology in specific context of our research would impose certain drawbacks, since frequency of Type I and Type II errors calculated this way may be somewhat misleading. For instance, the owners of a business entity can voluntarily liquidate its assets and cease its operations. In this case, nonmodified audit opinions from the preceding periods are not actual misjudgments. Also, in the context of the Serbian economy and our research sample, it is significantly more likely for medium-sized entities (which would otherwise be classified as small-sized in terms of global standards) to be liquidated than for an S\&P 500 listed entity. Moreover, the described approach would considerably reduce the research sample size, since the number of companies that entered into default, and have detailed financial data publicly available, is rather insignificant. Considering previously stated methodological limitations, we believe that this can be avoided in the case of developing countries, by assuming a different approach to measuring audit quality. In the following paragraph, we describe a methodological approach that is more pragmatic, as it makes better use of the available financial data.

In order to draw relevant conclusions regarding the research subject, we have defined, identified and removed the outliers. Financial statements from the initial sample are left out if they do not meet the following requirements: calculated values of average monthly salary can take values in the range from $€ 30$ to $€ 3,000$; moreover, net margin is expected to be between $-300 \%$ and $300 \%$. Upon outlier treatment, the initial sample was reduced to 10,555 financial statements for the reporting period 2010-2012.

Subsequently, we gathered audit reports of entities included in the sample, and noted whether they were issued by the Big 4 or not. Then, based on the previous criterion, we split the sample in two parts: the first, which is called the "training sample", included opinions issued by the Big 4; the second, called the "test sample", included the opinions of the rest of the audit firms. It turns out that the members of the Big 4 audited 1,101 financial statements, whereas 9,454 
were audited by the remaining auditors. Finally, a dummy coded dependent variable is defined based on the actual audit opinions stated in the auditor reports ( 1 = modified opinion; 0 = unmodified opinion). To sum up, calculated financial indicators (see Table 1) are treated as explanatory variables in the process of classification, and audit opinions constitute the binary response variable.

Classification process can be performed by means of various statistical (or machine learning) methods. In this research, we have used family of classifiers named "Decision trees". Specifically, we used the IBM SPSS implementation of Exhaustive CHAID algorithm. This is a superior algorithm compared to regular CHAID because it has improved its ability to find an optimal method of grouping the categories for each predictor. CHAID uses a chi-squared statistics (hence the C and $\mathrm{H}$ in its name) for node splitting. We have used its likelihood ratio form of estimation, which is more robust than Pearson's, but also requires more time for calculation. Moreover, we did so in order to take advantage of modern computational power. Nodes in the decision trees are presented in a top-down manner, each with its own corresponding key statistics. In the results section, we also present the classification risk and the gain statistics for each node. The stopping criterion is set to activate if the number of iterations exceeds 100 or the change in expected cell frequencies falls below 0.001 . The minimum number of cases per node has been set to 90 for parent nodes and 30 for child nodes. We have used a split-sample valida- tion sub command for the Big 4 in order to evaluate how well the tree structure will generalize to a larger population (in this case, to the test sample). In order to make the significance level adequately conservative, the Bonferroni adjustment is applied.

Above all other reasons, the decision tree family of classifiers was selected for its transparency, as well as for the interpretability of its output (which is in the form of classification rules). This is particularly true when compared to some other advanced machine learning algorithms (e.g. Neural Networks). Furthermore, they have the capacity to detect and account for non-linear effects on the response variable or interactions between predictors (Ritschard, 2010), which is, in view of the problem of interest, another advantageous feature. Linear models are transparent too, but they lack the aforementioned capability of accounting for non-linear effects and interactions between predictors.

\section{RESULTS}

In the initial phase, we have trained the classification algorithm based on the values of financial indicators and corresponding opinions issued by the Big 4 audit firms (the test sample). The tree is grown starting at the root node by repeatedly performing three steps at each node: merging, splitting and stopping.

This stage provided key insights into the financial indicators that are considered to have the best discriminatory power (i.e. the strength of association be-

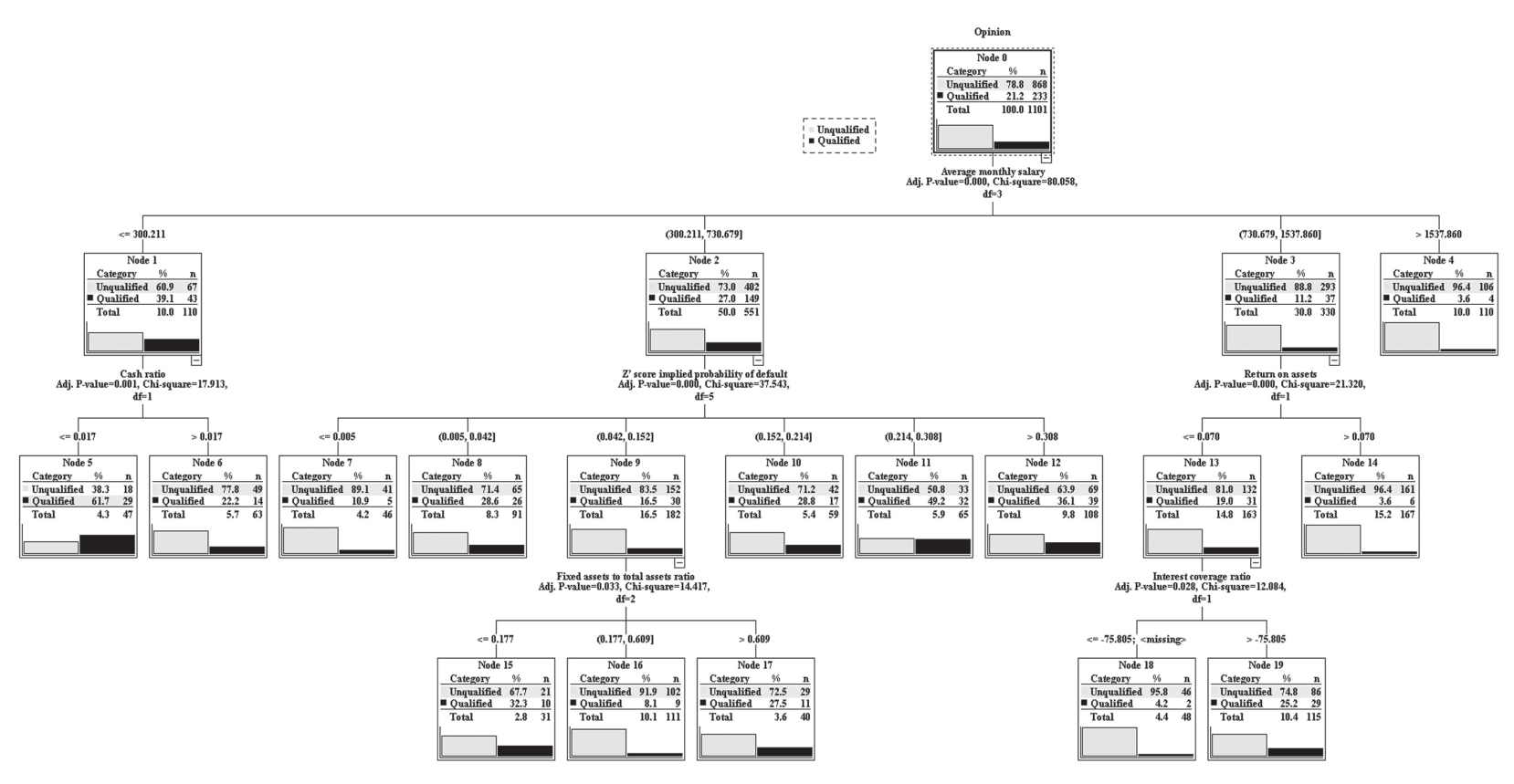

Figure 1. Classification rules inferred from the training sample (Big 4 clients) 
tween independent variable (predictor) and dependent variable) between entities that received an unmodified opinion and those that received a modified one.

The first diagram illustrates the fact that the training sample of 1,101 audit opinions (868 unmodified and 233 modified) has been divided at node 0 , based on the values of average monthly salary to nodes 1 (less than \$300,211), 2 (between $\$ 300,211$ and $\$ 730,679$ ), 3 (between $\$ 730,679$ and $\$ 1,537,860$ ) and 4 (more than $\$ 1,537,860$ ). At the second level, cash ratio, Z'- score implied probability of default and return on assets have been used for further classification. By analyzing the node that is first from the left on the second level of the decision tree, we notice that the entities have been further classified based on their cash-ratio values. This leads us to the conclusion that these are the entities with acute financial problems, but that are expected to deal with short-term liquidity issues. The next node of the second level of classification is likely to comprise entities that have significant mid-to-long term solvency issues, since their Z'-score values turn out to be an important discriminator. Again, the next node to the right, which contains $40 \%$ of entities, is further classified based on their return on assets and interest coverage ratio values. A possible explanation for this is that companies that are not faced with liquidity or solvency issues are generally more likely to engage in earning(s) management activities if their result (ROA) is closer to the borderline, or if they bear the burden of repaying relatively high loan amounts.
Stanišić, N. et al. $\diamond$ Defining second-tier audit firms in Serbia

In order to identify members of the second tier, we have used the very same rules of classification on the test sample, which consisted of audit opinions issued by other audit firms (other than members of the Big 4). The underlying assumption is that the audit methodology used by the Big 4 is probably superior to that of other auditors. Hence, our goal is to determine the firms which use an audit methodology that seems to be most similar to that of the Big 4. The classification tree is illustrated in the following diagram.

Table 2 shows the observed classification consistency. The risk estimate is the proportion of properly classified cases.

\begin{tabular}{ccc}
\hline Sample & Estimate & Standard Error \\
\hline Training & .202 & .012 \\
\hline Test & .337 & .005
\end{tabular}

Table 2. The risk of improper classification of training and test sample

The risk of wrong classification is higher for the test sample. There are three possible theoretical explanations for this. The first one is model over fitting. This is an error which occurs when a model so closely fits the training sample that, in addition to those characteristics of key interest, it ends up including those that are of a random (noise) nature. As a result, the model is expected to have a significant drop in classification performance when applied to the test sample.

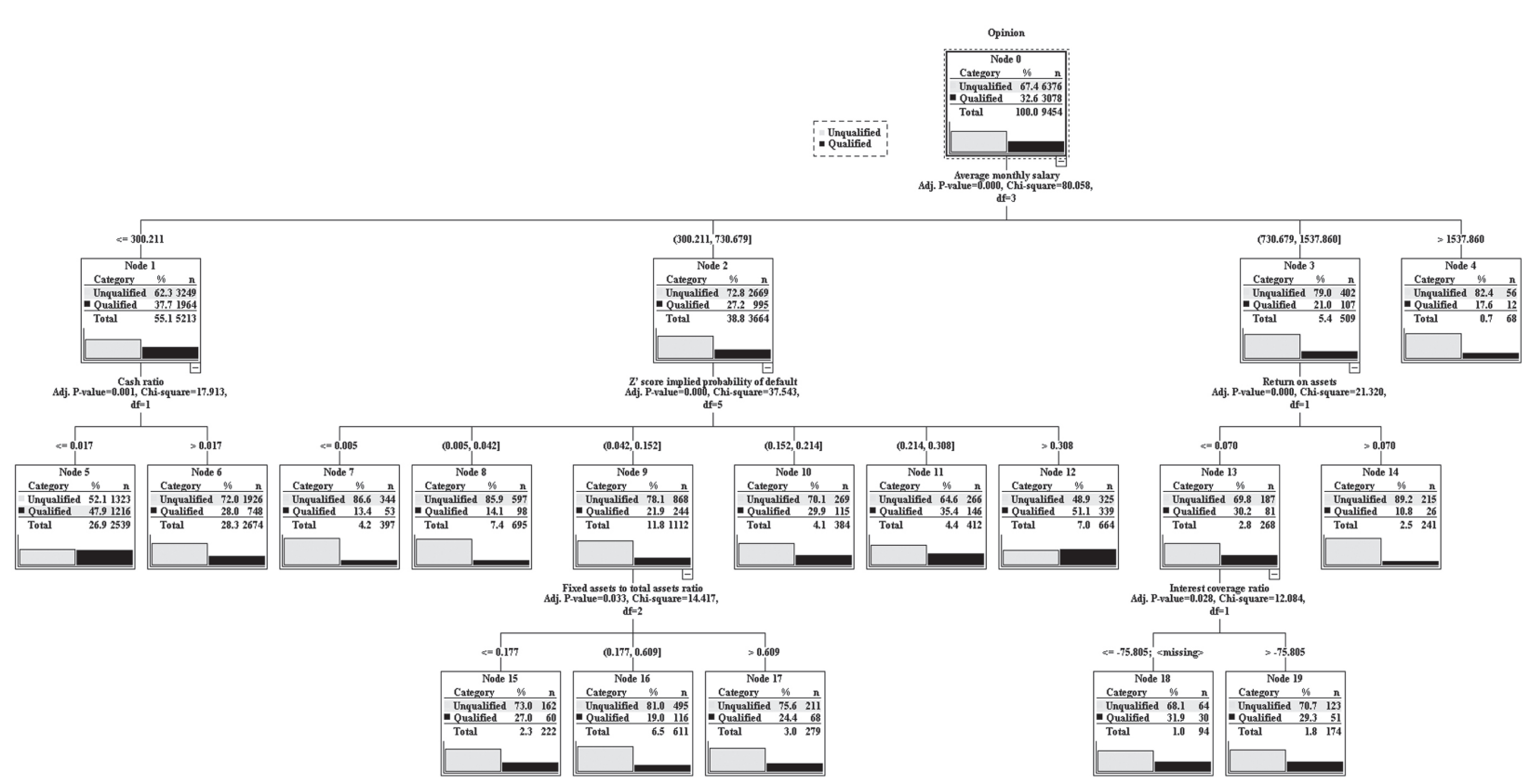

Figure 2. Decision tree and classification rules for training sample (remaining audit firms - non-Big 4) 
The second reason is related to different characteristics of clients between the two samples. To be precise, it can be argued that entities that have poor financial performance face somewhat different challenges compared to their healthy counterparts. For instance, smaller businesses may more frequently receive a going-concern notice, since they have limited access to additional capital funding (lack of financial flexibility), inaccurate financial reporting (inadequately trained accountants) and lower overall liquidity levels. The same holds for state-owned entities. Research conducted by Radak and Bukvić (2010) shows that only a tiny fraction of state-owned entities are clients of the Big 4 firms. The authors claim that those entities typically have low profitability, messy financial reporting practices and are highly motivated to apply undesirable creative accounting techniques. Consequently, they usually try to evade the "rigorous" controls employed by top auditors, and thus tend to resort to other smaller auditors. Such clients may introduce higher audit risk (predominately more Type II errors) in second and third-tier auditors' portfolios, which adversely impact their profitability. Therefore, the discriminative power of both cash ratio and Z'-score is greater for the non-Big 4 clients. Regarding the risks that non-Big 4 audit firms face, it is important to notice that the state-owned entities in the Republic of Serbia are found to be particularly risky clients.

The third reason, and probably the most significant for this research, is the level of quality of audit service. In other words, the non-Big 4 audit firms may have low classification accordance with the Big 4 firms simply because they provide lower quality audit services (lack of appropriate training, knowledge, resources, etc.).

We have compared the actual type of audit opinions assigned to certain entities with predicted values generated by classification rules. The results are summarized in Table 3.
The classification errors are drastically higher for the test sample $(79.8 \%$ compared to $66.3 \%$ for the training sample). The firms in the test sample (nonBig 4 audit firms) are precise in relation to the issuance of modified opinions (i.e. have less Type I errors), but significantly imprecise in issuing unmodified opinion (i.e. have more Type II errors).

We also notice significant difference in the incidence of classification errors among the non-Big 4 firms. In the following table, we have presented the list of audit firms, listed based on the descending value of accordance with Big 4 classification rules. Specifically, in the context of this research, higher values of accordance metrics are assumed to be more favorable.

Table 4 displays the second-tier auditing firms in Serbia (the Small 4): Privredni Savetnik, Stanisic Audit, Vincic and Savica. These are the firms with lowest observed ratio of misclassification (in the context of the research) to total opinions, which means that their audit methodology is relatively similar to that of the Big 4 (at least relatively similar compared to the rest of the firms). It is interesting to notice that the members of the Small 4 are not the most profitable audit firms in Serbia (Jakšić et al., 2012). We should also point out that Privredni Savetnik and Stanisic Audit appear to have greater market share than the other two members of the Small 4. Therefore, since Vincic and Savica have a relatively low number of audits performed, it is plausible that they will lose their status in the foreseeable future, while Revizija and SBV Jankovic have a good opportunity to take over their positions. Also, it is worth noting that Stanisic Audit and Savica have more Type I errors, whereas Privredni Savetnik and especially Vincic have more Type II errors.

At this point, it is important to bear in mind that the predicted values are neither based on the percentage of entities that went bankrupt during the observed

\begin{tabular}{ccccc}
\hline \multirow{2}{*}{ Sample } & Observed & \multicolumn{3}{c}{ Predicted } \\
\cline { 2 - 5 } & & Unmodified & Modified & Percent correct \\
\hline \multirow{3}{*}{ Training } & Unmodified & 850 & 18 & $97.9 \%$ \\
\cline { 2 - 5 } & Modified & 204 & 29 & $12.4 \%$ \\
\cline { 2 - 5 } & Overall percentage & $95.7 \%$ & $4.3 \%$ & $79.8 \%$ \\
\hline \multirow{3}{*}{ Test } & Unmodified & 5053 & 1,323 & $79.3 \%$ \\
\cline { 2 - 5 } & Modified & 1,862 & 1,216 & $39.5 \%$ \\
\cline { 2 - 5 } & Overall percentage & $73.1 \%$ & $26.9 \%$ & $66.3 \%$ \\
\hline
\end{tabular}

Table 3. The impreciseness of classification of the training and test samples 


\begin{tabular}{|c|c|c|c|c|c|c|c|c|c|}
\hline & \multicolumn{8}{|c|}{ Error } \\
\hline & & \multicolumn{2}{|c|}{ No error } & \multicolumn{2}{|c|}{ Type I error } & \multicolumn{2}{|c|}{ Type II error } & \multicolumn{2}{|c|}{ Total } \\
\hline & & Count & Row N \% & Count & Row N \% & Count & Row N \% & Count & Row N \% \\
\hline \multirow{42}{*}{ 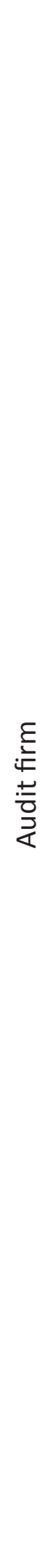 } & Privredni Savetnik & 179 & $86.1 \%$ & 11 & $5.3 \%$ & 18 & $8.7 \%$ & 208 & $100 \%$ \\
\hline & Stanisic Audit & 178 & $76.1 \%$ & 33 & $14.1 \%$ & 23 & $9.8 \%$ & 234 & $100 \%$ \\
\hline & Vincic & 40 & $75.5 \%$ & 2 & $3.8 \%$ & 11 & $20.8 \%$ & 53 & $100 \%$ \\
\hline & Savica & 46 & $75.4 \%$ & 8 & $13.1 \%$ & 7 & $11.5 \%$ & 61 & $100 \%$ \\
\hline & Revizija & 291 & $74.8 \%$ & 88 & $22.6 \%$ & 10 & $2.6 \%$ & 389 & $100 \%$ \\
\hline & SBV Jankovic & 115 & $71.9 \%$ & 40 & $25 \%$ & 5 & $3.1 \%$ & 160 & $100 \%$ \\
\hline & IEF & 263 & $71.9 \%$ & 52 & $14.2 \%$ & 51 & $13.9 \%$ & 366 & $100 \%$ \\
\hline & Euro Audit & 622 & $71.7 \%$ & 136 & $15.7 \%$ & 109 & $12.6 \%$ & 867 & $100 \%$ \\
\hline & Dij Audit & 256 & $70.5 \%$ & 46 & $12.7 \%$ & 61 & $16.8 \%$ & 363 & $100 \%$ \\
\hline & Alfa Revizija & 84 & $70 \%$ & 6 & $5 \%$ & 30 & $25 \%$ & 120 & $100 \%$ \\
\hline & PKF & 314 & $69.8 \%$ & 57 & $12.7 \%$ & 79 & $17.6 \%$ & 450 & $100 \%$ \\
\hline & Srbo Audit & 178 & $69.3 \%$ & 58 & $22.6 \%$ & 21 & $8.2 \%$ & 257 & $100 \%$ \\
\hline & Fineks SJ & 45 & $69.2 \%$ & 7 & $10.8 \%$ & 13 & $20 \%$ & 65 & $100 \%$ \\
\hline & Grant Thornton & 130 & $69.1 \%$ & 20 & $10.6 \%$ & 38 & $20.2 \%$ & 188 & $100 \%$ \\
\hline & Libra audit & 65 & $69.1 \%$ & 11 & $11.7 \%$ & 18 & $19.1 \%$ & 94 & $100 \%$ \\
\hline & Milinkovic audit & 105 & $68.6 \%$ & 16 & $10.5 \%$ & 32 & $20.9 \%$ & 153 & $100 \%$ \\
\hline & EKI revizija & 109 & $68.6 \%$ & 2 & $1.3 \%$ & 48 & $30.2 \%$ & 159 & $100 \%$ \\
\hline & Absolute Audit & 88 & $68.2 \%$ & 30 & $23.3 \%$ & 11 & $8.5 \%$ & 129 & $100 \%$ \\
\hline & Pan Revizija & 163 & $67.4 \%$ & 41 & $16.9 \%$ & 38 & $15.7 \%$ & 242 & $100 \%$ \\
\hline & Mdm revizija & 169 & $67.1 \%$ & 46 & $18.3 \%$ & 37 & $14.7 \%$ & 252 & $100 \%$ \\
\hline & Moore Stephens & 316 & $66.9 \%$ & 52 & $11 \%$ & 104 & $22 \%$ & 472 & $100 \%$ \\
\hline & Konsultant revizija & 170 & $65.9 \%$ & 20 & $7.8 \%$ & 68 & $26.4 \%$ & 258 & $100 \%$ \\
\hline & MC Global Audit & 27 & $65.9 \%$ & 6 & $14.6 \%$ & 8 & $19.5 \%$ & 41 & $100 \%$ \\
\hline & Revizija plus-pro & 177 & $65.6 \%$ & 29 & $10.7 \%$ & 64 & $23.7 \%$ & 270 & $100 \%$ \\
\hline & Kapital revizija & 38 & $65.5 \%$ & 11 & $19 \%$ & 9 & $15.5 \%$ & 58 & $100 \%$ \\
\hline & $\mathrm{BDO}$ & 119 & $64.7 \%$ & 2 & $1.1 \%$ & 63 & $34.2 \%$ & 184 & $100 \%$ \\
\hline & Prva revizija & 49 & $64.5 \%$ & 5 & $6.6 \%$ & 22 & $28.9 \%$ & 76 & $100 \%$ \\
\hline & ACA Professional Audit & 23 & $63.9 \%$ & 4 & $11.1 \%$ & 9 & $25 \%$ & 36 & $100 \%$ \\
\hline & Auditor & 174 & $63.5 \%$ & 25 & $9.1 \%$ & 75 & $27.4 \%$ & 274 & $100 \%$ \\
\hline & NDP & 36 & $63.2 \%$ & 4 & $7 \%$ & 17 & $29.8 \%$ & 57 & $100 \%$ \\
\hline & Bojic revizija & 49 & $62.8 \%$ & 16 & $20.5 \%$ & 13 & $16.7 \%$ & 78 & $100 \%$ \\
\hline & Fin Revizija & 120 & $61.9 \%$ & 47 & $24.2 \%$ & 27 & $13.9 \%$ & 194 & $100 \%$ \\
\hline & Dst revizija & 366 & $61.2 \%$ & 149 & $24.9 \%$ & 83 & $13.9 \%$ & 598 & $100 \%$ \\
\hline & Rang & 18 & $60 \%$ & 7 & $23.3 \%$ & 5 & $16.7 \%$ & 30 & $100 \%$ \\
\hline & Baker Tilly WB Revizija & 113 & $58.5 \%$ & 18 & $9.3 \%$ & 62 & $32.1 \%$ & 193 & $100 \%$ \\
\hline & Confida Finodit & 602 & $58.3 \%$ & 111 & $10.7 \%$ & 320 & $31 \%$ & 1033 & $100 \%$ \\
\hline & Pan audit & 32 & $58.2 \%$ & 2 & $3.6 \%$ & 21 & $38.2 \%$ & 55 & $100 \%$ \\
\hline & Europoint & 32 & $56.1 \%$ & 21 & $36.8 \%$ & 4 & $7 \%$ & 57 & $100 \%$ \\
\hline & Vizura Invent & 87 & $54.4 \%$ & 21 & $13.1 \%$ & 52 & $32.5 \%$ & 160 & $100 \%$ \\
\hline & LB Rev & 100 & $54.3 \%$ & 14 & $7.6 \%$ & 70 & $38 \%$ & 184 & $100 \%$ \\
\hline & Nova revizija & 29 & $52.7 \%$ & 21 & $38.2 \%$ & 5 & $9.1 \%$ & 55 & $100 \%$ \\
\hline & Auditing & 56 & $45.5 \%$ & 0 & $0 \%$ & 67 & $54.5 \%$ & 123 & $100 \%$ \\
\hline
\end{tabular}

Table 4. The impreciseness of classification of the training and test samples 
period, nor on the statistically estimated effects of earnings management practice. For that reason, any potential conclusions regarding audit service quality that might be drawn from the presented results are heavily dependent on the assumptions clearly stated in the previous sections of this paper. We suggest that the results should be viewed as comparative rather than absolute, and consequently interpreted in terms of accordance/discordance, rather than in terms of superiority/inferiority of services quality.

\section{SUMMARY}

In this paper, considerable effort has been devoted to defining second-tier audit firms in the Republic of Serbia. To that end, a large amount of data comprising 10,555 annual financial reports and corresponding audit opinions has been collected and analyzed. Relevant financial indicators have been calculated, and the initial sample has been divided between the training sample, comprising the statements audited by the Big 4, and the test sample, which included financial statements audited by other audit firms. Firstly, an Exhaustive CHAID classification algorithm has been trained on the test sample. The resulting classification rules have then been applied to the test sample, resulting in the predicted audit opinions. Finally, the differences (errors) between the predicted and observed opinions have been analyzed. As expected, second and third-tier auditors had relatively more Type II errors. As a final step, the predicted outcomes have been compared to the actual ones, and the discordance statistics have been calculated and summarized in a form of a table. Based on the results obtained, we have determined that Privredni Savetnik, Stanisic Audit, Vincic and Savica are the Small 4 audit firms operating on the territory of the Republic of Serbia. However, a follow-up analysis reveals that they are not the most profitable ones. Similarly, it seems that there is no clear association between the prevalence of errors and corresponding market share within the second and third-tier auditors, but we recommend that further research should be undertaken concerning this topic. The authors have also pointed out that there are significant methodological limitations to this research (see results section) and that its results should be interpreted with caution.

\section{REFERENCES}

Becker, C., Defond, M., Jiambalvo, J., \& Subramanyam, K. (1998). The effect of audit quality on earnings management. Contemporary Accounting Research, 15(1), 1-24. doi:10.1111/j.1911-3846.1998.tb00547.x

Campa, D. (2013). Big 4 fee premium and audit quality: Latest evidence from UK listed companies. Managerial Auditing Journal, 28(8), 680-707. doi:10.1108/ MAJ-11-2012-0784

Causse, D., \& Vu, V.H.T. (2012). Les dimensions de la performance des cabinets d'audit légal - Le point de vue des auditeurs. Comptabilité - Contrôle - Audit, 28(18), 97-143. doi:10.3917/cca.183.0097

Deangelo, L. (1981). Auditor size and audit quality. Journal of Accounting and Economics, 3(1), 183-199.

Defond, M. (1992). The association between changes in client firm agency costs and auditor switching. Auditing: $A$ Journal of Practice \& Theory, 11(1), 16-31.

Dey, M., \& Robin, A. (2011). Second-tier auditing firms: Developments and prospects. The CPA Journal, 81(6), 32-39.

Geiger, M., \& Rama, D. (2006). Audit firm size and goingconcern reporting accuracy. Accounting Horizons, 20(1), 1-17. doi: 10.2308/acch.2006.20.1.1

Geiger, M., Raghunandan, K., \& Riccardi, W. (2014). The global financial crisis: U. S. bankruptcies and goingconcern audit opinions. Accounting Horizons, 28(1), 59-75. doi:10.2308/acch-50659

Hogan, C., \& Martin, R. (2009). Risk shifts in the market for audits: An examination of changes in risk for "second tier" audit firms. Auditing: A Journal of Practice \& Theory, 28(2), 93-118.

Jakšić, D., Mijić, K., \& Andrić, M. (2012). Analysis of variations in the performance of audit firms in the Republic of Serbia. Economic Annals, 57(193), 71-91. doi:10.2298/EKA1293071J

Palmrose, V. (1988). An analysis of auditor litigation and audit service quality. The Accounting Review, 63(1), 55-73.

Radak, I., \& Bukvić, L. (2010). Javna preduzeća beže od stroge revizije. Retrieved September 14, 2014, from http:// www.danas.rs/danasrs/ekonomija/javna_preduzeca_ beze_od_stroge_revizije.4.html?news_id=188710

Ritschard, G. (2010). CHAID and Earlier Supervised Tree Methods. Retreived September 14, 2014, from http:// ideas.repec.org/p/gen/geneem/2010.02.html

Tsipouridou, M., \& Spathis, C. (2012). Earnings management and the role of auditors in an unusual IFRS context: The case of Greece. Journal of International Accounting, Auditing and Taxation, 21(1), 62-78. doi:10.1016/j.intaccaudtax.2012.01.005

Yaşar, A. (2013). Big Four auditors' audit quality and earnings management: Evidence from Turkish Stock Market. International Journal of Business and Social Science, 4(17), 153-163. 


\section{ODREĐIVANJE DRUGOG NIVOA REVIZORSKIH FIRMI U REPUBLICI SRBIJI: U POTRAZI ZA “MALOM ČETVORKOM”}

\section{Rezime:}

U ovom radu pokušaćemo da definišemo drugi nivo revizorskih firmi u Republici Srbiji. Kako bismo ostvarili cilj rada, analizirali smo 10.555 finansijskih izveštaja pravnih lica koja posluju na teritoriji Republike Srbije, a koji su pripremljeni za period od 2010. do 2012. godine. Od ukupnog pomenutog broja, eksternu reviziju 1.101 izveštaja uradila je "Velika četvorka", dok je reviziju druge grupe izveštaja uradilo preostalih 38 revizorskih firmi. U cilju definisanja algoritma klasifikacije, kao nezavisnu varijablu upotrebili smo izračunate finansijske pokazatelje, dok smo za zavisnu varijablu koristili tip revizorskog mišljenja koji je izdat od strane "Velike četvorke". Primenom metode stabla odlučivanja dobili smo pravila razvrstavanja, koja smo kasnije primenili na uzorku privrednih društava za čiju reviziju su bile zadužene preostale revizorske firme. Na osnovu poklapanja sa kriterijumima "Velike četvorke" (za koju važi da poseduje visok nivo kvaliteta izvršene revizije), od uzorkovanih revizorskih firmi predložili smo one koje bi činile "Malu četvorku" u Republici Srbiji. Pored pomenutog, rezultati istraživanja ukazuju na to da "Velika četvorka" i preostale revizorske firme ne posvećuju podjednaku pažnju pojedinim finansijskim pokazateljima. Mogući razlozi za to su prethodno razmotreni u radu. Na kraju, autori će pokušati da predlože u kom pravcu bi mogla da se kreću buduća istraživanja na ovu temu.

\section{Ključne reči:}

stablo odlučivanja, finansijski izveštaji, revizorsko mišljenje.

Received: April 5, 2015.

Correction: April 10, 2015.

Accepted: May 2, 2015. 